\title{
PENGARUH DOSIS PUPUK KCL DAN JENIS MULSA TERHADAP PERTUMBUHAN UBI JALAR (Ipomoea batatas L.)
}

\author{
Suryanto $^{\left.1^{*}\right)}$, Mukhlis ${ }^{2 *}$ \\ ${ }^{1,2 *}$ Fakultas Pertanian Universitas Muhammadiyah Tapanuli, Sumatera Utara
}

\begin{abstract}
ABSTRAK
Penelitian ini telah dilaksanakan di kebun percobaan Fakultas Pertanian Universitas Muhammadiyah tapanuli selatan, dari bulan Mei sampai pada bulan Agustus tahun 2017.Tujuan penelitian ini adalah untuk mengetahui Pengaruh dosis pupuk KCl dan jenis mulsa terhadap pertumbuhan.Rancangan yang di gunakan adalah Faktorial 4 x 3 dalam rancangan acak kelompok (RAK) dengan 3 ulangan. Faktor pertama dosis pupuk $\mathrm{KCl}(\mathrm{K})$ dengan 4 tarap yaitu : dosis $150 \mathrm{~kg} / \mathrm{ha}$, dosis $300 \mathrm{~kg} / \mathrm{ha}$, dosis $450 \mathrm{~kg} / \mathrm{ha}$ dan dosis $600 \mathrm{~kg} / \mathrm{ha}$. Faktor kedua jenis mulsa (M) dengan 3 tarap yaitu : tanpa mulsa, mulsa jerami, mulsa plastik hitam perak. Data hasil pengamatan dianalisis secara statistik menurut uji $\mathrm{F}$ pada taraf 5\%. Jika F hitung lebih besar dari F tabel 5\% berarti berpengaruh berbeda nyata maka dilanjutkan dengan Duncan's New Multiple Range Test (DNMRT). Interaksi antara dosis pupuk dan jenis mulsa berpengaruh nyata terhadap jumlah daun umur 6 MST, indeks luas daun umur 35 HST dan umur 42 HST, laju asimilasi bersih umur 35 HST. Selanjutnya dosis pupuk KCl berpengaruh nyata terhadap jumlah cabang, jumlah daun umur 4 MST dan umur 6 MST. Jenis mulsa berpengaruh nyata terhadap jumlah daun umur 7 MST.
\end{abstract}

Kata Kunci : Pupuk KCL, Jenis Mulsa, Ubi Jalar

\section{PENDAHULUAN}

Ubi jalar (Ipomoea batatas L.) diduga berasal dari Amerika Tengah. Ubi jalar menyebar ke seluruh dunia, terutama negara-negara beriklim tropis, pada abab ke -16 penyebaran ubi jalar ke Asia, terutama Filipina, Jepang, dan Indonesia dilakukan oleh masyarakat Spanyol (Purwono dan Purnamawati, 2007).

Masuknya ubi jalar ke Indonesia bermula dari kedatangan bangsa Spanyol dan Portugis. Saat ini, tanaman ubi jalar telah ditanam hampir di seluruh wilayah sekitar khatulistiwa, yaitu 
antara $40^{\circ} \mathrm{LU}$ dan $32^{0} \mathrm{LS}$. Di wilayah tersebut ubi jalar sangat penting karena sebagai sumber pangan dan pakan alternatif bagi negara-negara Asia dan pulau-pulau di Pasifik (Sonhaji, 2007).

Ubi jalar (Ipomoea batatas L.) dapat menjadi bahan makanan pokok dan selingan bagi penduduk untuk mengurangi kebutuhan konsumsi beras yang terus meningkat. Kandungan kimia ubi jalar cukup baik untuk dijadikan bahan pangan. Komposisi kimia ubi jalar sebagian besar terdiri atas air 72,8\%, dan karbohidrat 24,3\%, sedangkan komponen lainnya seperti protein, lemak, vitamin, dan mineral, sangat tergantung pada faktor genetik dan kondisi penanamannya. Dengan demikian, ubi jalar merupakan sumber pangan berenergi, yaitu dalam bentuk gula atau karbohidrat. Selain itu, ubi jalar juga mengandung berbagai vitamin dan mineral yang dibutuhkan oleh tubuh, seperti kalsium dan zat besi, serta vitamin A dan C (Richana, 2012).

Produksi tanaman ubi jalar pada propinsi Sumatera Utara di tahun 2015 sebesar 122.362 ton, dan tahun 2020 ditargetkan sebesar 210.776 ton (Dessy et al., 2015). Untuk mencapai target peningkatan produksi ubi jalar ditahun 2020 maka berbagai upaya dilakukan salah satunya adalah dengan pemberian pupuk KCL.

Untuk meningkatkan produksi ubi jalar adalah dengan melakukan pemupukan. Ubi jalar membutuhkan banyak unsur $\mathrm{K}$ dari pada unsur $\mathrm{N}$ dan $\mathrm{P}$ untuk produksi umbi. Zat hara kalium (K) meningkatkan pembentukan bunga dan klorofil, meningkatkan pembentukan zat gula, meningkatkan pembentukan karbohidrat, meningkatkan daya serap air, meningkatkan kekuatan daun, meningkatkan pembesaran umbi, dan meningkatkan daya tahan terhadap penyakit (Juanda dan Bambang, 2000).

Tersedianya K yang cukup memberikan kondisi penggunaan air yang lebih efisien seperti terpeliharanya turgor sehingga memungkinkan lancarnya proses metabolisme, $\mathrm{K}$ terutama terakumulasi pada organ-organ tanaman yang muda seperti pada pucuk, tunas dan akar, akumulasi K akan membentuk jaringan korteks dalam perpanjangan sel-sel muda (Tisdale et 
al. 1990). Kalium juga penting dalam menjamin akar tetap menyerap air secara maksimal karena meningkatkan nilai osmotik, hal ini memungkinkan sekresi ion-ion ke dalam sel akar yang mendesak osmotik ke vesikular dan jaringan lainnya (Poerwowidodo, 1992).

Mulsa adalah bahan yang dipakai untuk menutupi tanah dan berfungsi untuk menjaga penguapan air dalam tanah, memelihara struktur tanah dan menekan pertumbuhan gulma (Mariano, 2003). Selain itu mulsa berfungsi untuk menekan pertumbuhan gulma, mempertahankan agregat tanah dari hantaman air hujan, memperkecil erosi permukaan tanah, mencegah penguapan air, dan melindungi tanah dari terpaan sinar matahari, juga dapat membantu memperbaiki stabilitas agregat tanah (Thomas et al. 1993).

Penanaman tanaman penutup tanah dan penutupan permukaan tanah dengan sisa-sisa tanaman merupakan teknik konservasi secara vegetatif/kultur teknis yang mudah dilaksanakan. Adanya tanaman penutup tanah dan mulsa organik dapat menahan percikan air hujan dan aliran air di permukaan tanah sehingga pengikisan lapisan atas tanah dapat ditekan (Nelson et al. 1991, Anwarudinsyah et al. 1993). Sumiati (2005) menyatakan mulsa plastik hitam perak berguna untuk melindungi tanaman dari air hujan yang jatuh ke permukaan tanah serta memercik ke batang, daun terbawah, dan buah. Percikan air hujan bercampur tanah yang berasal dari bedengan tanpa mulsa, dapat membawa patogen tular tanah berbahaya yang mengganggu pertumbuhan atau kesehatan tanaman pokok.

\section{BAHAN DAN METODE}

Percobaan ini telah dilaksanakan pada bulan Mei sampai dengan Agustus 2017 di Universitas Muhammadiyah Tapanuli Selatan, Kecamatan Padangsidimpuan Utara, Kota Padangsidimpuan, tinggi tempat 321 meter di atas permukaan laut.

Bahan yang digunakan adalah Bibit ubi jalar Varietas Antin1, pupuk KCl, pupuk TSP, pupuk UREA, Mulsa plastik hitam perak, mulsa jerami padi, insektisida, fungisida, dosis dan waktu pengendalian disesuaikan dengan keadaan di lapangan. 
Alat yang digunakan Alat yang digunakancangkul, parang, martil, meteran, tali rapia, timbangan analitik, ember, mesin air, semprot solo, jangka sorong, oven, papan nama, patok, penggaris, alat tulis.

\section{Metode Penelitian}

Penelitian menggunakan rancangan faktorial 4 x 3 dalam Rancangan Acak Kelompok (RAK) dengan 3 ulangan. Faktor utama adalah dosis pupuk $\mathrm{KCl}$ yang terdiri dari empat taraf, dan faktor kedua penggunaan mulsa yang terdiri dari tiga taraf.Faktor pertama dosis pupuk $\mathrm{KCl}$ (K) dengan 4 taraf, yaitu :K1 = 3,75 g/tanaman $(150 \mathrm{~kg} / \mathrm{ha}) \mathrm{K} 2=$ = 7,5 g/tanaman $(300 \mathrm{~kg} /$ ha) $\mathrm{K} 3=11,25 \mathrm{~g} / \operatorname{tanaman}(450 \mathrm{~kg} / \mathrm{ha}) \mathrm{K} 4=15 \mathrm{~g} / \operatorname{tanaman}(600 \mathrm{~kg} / \mathrm{ha})$. Faktor kedua adalah perlakuan Mulsa (M) dengan 3 taraf yaitu M1:Tanpa mulsa, M2 : Mulsa jerami, M2: Mulsa plastik hitam perak

Untuk melihat pengaruh perlakuan pada parameter yang di uji, maka dilakukan uji statistik dengan menggunakan uji $\mathrm{F}$ pada taraf 5\%. Jika $\mathrm{F}$ hitung lebih besar dari $\mathrm{F}$ tabel 5\% berarti berpengaruh atau berbeda nyata maka dilanjutkan dengan Duncan's New Multiple Range Test (DNMRT). Pengamatan periodik ditampilkan dalam bentuk grafik.

\section{Variabel Respon}

Data yang digunakan untuk menganalisis pertumbuhan tanaman ubi jalar melalui perhitungan berbagai karakteristik tumbuh tanaman ubi jalar adalah data periodik bobot kering total tanaman, luas daun, dan bobot kering umbi, disamping satuan luas yang dipakai. Data tersebut diperolehdari empat tanaman sampel yang ditimbang atau diukur pada umur 28 hari, 35 hari, 42 hari, 49 hari setelah tanam. Tanaman sampel yang dikeringkan dalam oven pada suhu $70{ }^{\circ} \mathrm{C}$ ditimbang untuk memperoleh bobot kering total tanaman. Pengeringan dilakukan selama 48 jam sampai bobot kering tanaman tetap. Luas daun diukur dengan menggunakan kertas milimeter. Karakteristika tumbuh tanaman dihitung dengan menggunakan berbagai formula (Gardner et al., 1991), yaitu: 
1.Panjang tanaman (cm).

Pertumbuhan tanaman ubi jalar dilakukan dengan mengukur panjang tanaman yang dilakukan setiap satu minggu sekali. Pengukuran tinggi tanaman dimulai dari batang bawah sampai ujung tunas dengan menggunakan meter. Pengamatan panjang tanaman dilakukan pada umur 2, 3, 4, 5, 6 dan 7 minggu setelah tanam.

2.Jumlah Cabang (batang)

Pertumbuhan tanaman ubi jalar dilakukan dengan menghitung jumlah cabang, yang dilakukan setiap satu minggu sekali. Pengamatan jumlah cabang diamati pada tanaman yang telah mengeluarkan cabang yang sudah berdaun dua. Pengamatan jumlah cabang dilaksanakan pada umur 4, 5, 6 dan 7 minggu setelah tanam.

3. Jumlah daun (daun).

Pertumbuhan tanaman ubi jalar dilakukan dengan menghitung jumlah daun yang dilakukan setiap satu minggu. Pengamatan jumlah daun diamati pada daun yang sudah terbuka sempurna. Pengamatan jumlah daun dilaksanakan pada umur 4, 5, 6 dan 7 minggu setelah tanam.

\section{4 .Laju Tumbuh Tanaman Rata-rata (LTT )}

Laju Tumbuhan Tanaman (LTT) merupakan laju pertambahan berat kering biomassa total tanaman per satuan luas tanah per satuan waktu rata rata selama periode waktu tertentu. Pengamatan dilakukan di umur 28, 35, 42 dan 49 hari sesudah tanam, dengan menggunakan rumus :

$$
\mathrm{LTT}=\frac{\mathrm{W}_{2}-\mathrm{W}_{1}}{\mathrm{~A}\left(\mathrm{t}_{2}-\mathrm{t}_{1}\right)} \mathrm{mg} \mathrm{cm}^{-2} \text { hari }^{-1}
$$

\section{Indeks Luas Daun Rata-rata (ILD )}

Indeks luas daun (ILD) adalah suatu peubah yang menunjukkan hubungan antara luas daun dan luas bidang tanah yang ditutupi. Laju perubahan nilai ILD sangat tergantung pada kualitas metabolisme dalam pertumbuhan tanaman. Secara konvensional nilai ILD dilakukan 
dengan mengukur dan mengakumulasikan jumlah luas daun dalam satu bidang tertentu dan dibagi dengan luas bidang tersebut. Pengukuran dilakukan pada sampel destruktif di umur 28, 35, 42 dan 49 hari sesudah ditanam, dihitung dengan rumus:

$\mathrm{ILD}=\frac{\mathrm{L} 2+\mathrm{L} 1}{2 \mathrm{~A}}$

\section{Laju Asimilasi Bersih Rata-rata (LAB )}

Laju Asimilasi Bersih (LAB) merupakan laju pertambahan bahan kering total tanaman per satuan luas daun per satuan waktu selama periode waktu tertentu yang menggambarkan ratarata (mingguan) laju fotointesis bersih (kapasitas bahan tanaman mengakumulasikan bahan kering) per $\mathrm{cm}^{2}$ luas daun per minggu. Pengamatan mulai dilakukan saat umur 28, 35, 42, dan 49 hari setelah tanam, dengan menggunakan rumus:

$$
\mathrm{LAB}=\frac{\mathrm{W}_{2}-\mathrm{W}_{1}}{\mathrm{t}_{2}-\mathrm{t}_{1}} \times \frac{\ln \mathrm{L}_{2}-\mathrm{lnL}_{1}}{\mathrm{~L}_{2}-\mathrm{L}_{1}} \mathrm{mg} \mathrm{cm}^{-2} \operatorname{hari}^{-1}
$$

\section{HASIL DAN PEMBAHASAN}

1. Panjang Tanaman (cm)

Pertumbuhan vegetatif tanaman dapat diukur dengan mengamati beberapa parameter pertumbuhan. Adapun hasil pengamatan penambahan panjang tanaman dapat dilihat di Tabel 1 sebagai berikut :

Tabel 1. Panjang tanaman umur 7 MST pada berbagai dosis KCl dan jenis mulsa

\begin{tabular}{lccc}
\hline Perlakuan & \multicolumn{3}{c}{ Jenis Mulsa } \\
\cline { 2 - 4 } Dosis KCl (g/tan) & Tanpa Mulsa & Mulsa Jerami & Mulsa plastik \\
\hline 3.75 gram & 85.33 & 89.67 & 96.00 \\
7.5 gram & 94.00 & 100.67 & 96.00 \\
11.25 gram & 106.33 & 93.33 & 92.00 \\
15 gram & 97.00 & 108.00 & 95.00 \\
\hline
\end{tabular}

Pada Tabel 1. menunjukkan hasil tidak ada perbedaan yang nyata antara panjang tanaman akibat aplikasi dosis pupuk, jenis mulsa dan interaksi dosis pupuk dan jenis mulsa. Namun dapat diketahui ada kecenderungan bahwa aplikasi pupuk kalium dapat meningkatkan 
panjang tanaman, hal tersebut dapat dilihat semakin ditambah dosis pupuk $\mathrm{KCl}$ maka panjang tanaman juga meningkat, walaupun hal tersebut tidak nyata namun berdasarkan data di Tabel 1. dapat dijelaskan bahwa penambahan pupuk kalium berperan secara tidak langsung dalam peningkatan panjang tanaman. Mekanisme bertambahnya panjang tanaman tersebut ada berkaitan secara tidak langsung terhadap pertumbuhan tanaman. Bahwa, kalium berperan dalam sistem transportasi hara, dimana kalium berperan dalam pengangkutan unsur hara dari dalam tanah ke bagian tajuk dan kalium juga berperan dalam transportasi hasil assimilat ke seluruh bagian vegetatif tanaman.

Aplikasi mulsa jerami menunjukkan penambahan panjang tanaman yang lebih baik . Aplikasi mulsa jerami dapat menjaga suhu permukaan tanah yang lebih baik dibandingkan dengan mulsa plastik, sehingga hal tersebut diduga mampu memacu pertumbuhan tanaman menjadi lebih baik. Penambahan panjang tanaman merupakan proses pembelahan sel secara vertikal yang dipengaruhi oleh berbagai faktor. Syukur et al. (2010) menjelaskan bahwa pertumbuhan tanaman merupakan hasil dari pengaruh genetik dengan lingkungan.

\section{Jumlah Cabang}

Berdasarkan lampiran 15 hasil sidik ragam diperoleh dosis pupuk KCl menunjukkan pengaruh yang nyata, sedangkan jenis mulsa dan interaksi tidak berpengaruh nyata. Adapun hasil pengamatan pada pertumbuhan jumlah cabang dapat dilihat di Tabel 2

Tabel 2. Jumlah cabang ubi jalar umur 7 MST pada pemberian dosis KCl dan jenis mulsa

\begin{tabular}{lcccc}
\hline \multicolumn{1}{c}{ Perlakuan } & \multicolumn{3}{c}{ Jenis Mulsa } & \multirow{2}{*}{ Rata-rata } \\
\cline { 1 - 4 } Dosis KCl (g/tan) & $\begin{array}{l}\text { Tanpa } \\
\text { mulsa }\end{array}$ & $\begin{array}{c}\text { Mulsa } \\
\text { Jerami }\end{array}$ & $\begin{array}{c}\text { Mulsa } \\
\text { Plastik }\end{array}$ & \\
\hline 3.75 gram & 15.33 & 15.33 & 15.33 & $15.33 \mathrm{~b}$ \\
7.5 gram & 15.33 & 15.33 & 15.67 & $15.44 \mathrm{~b}$ \\
11.25 gram & 16.33 & 17.33 & 18.00 & $17.22 \mathrm{a}$ \\
15 gram & 18.33 & 18.33 & 18.00 & $18.22 \mathrm{a}$ \\
\hline
\end{tabular}

Keterangan :angka yang ditunjukkan oleh huruf yang sama pada kolom yang sama menunjukkan tidak berbeda nyata berdasarkan uji Duncan pada taraf $\alpha-5 \%$ 
Berdasarkan pada Tabel 2. dapat diketahui bahwa jumlah cabang ubi jalar dengan pemberian kalium tertinggi terdapat pada pemberian dosis pupuk $\mathrm{KCl} 15 \mathrm{~g} / \mathrm{tanaman}$ (600 kg/ha) dan 11,25g/ha yaitu 18,22 dan 17,22, terendah terdapat pada dosis pupuk KCl 3,5 g/tanaman (150 $\mathrm{kg} / \mathrm{ha}$ ) yaitu 15,33. Berdasarkan hal tersebut dapat diketahui bahwa pada jumlah cabang pupuk kalium berperan penting dalam pembentukan jumlah cabang. Damanik, et al. (2010) menjelaskan bahwa kalium merupakan unsur makro yang berperan dalam proses transportasi hara dalam sel. Jadi dengan keberadaan kalium yang semakin meningkat maka akan mendorong terjadinya regenerasi sel baru pada bagian batang sehingga dapat menumbuhkan cabang yang baru.

Jika dilihat berdasarkan perlakuan mulsa diketahui bahwa tidak menunjukan perbedaan antara tanpa mulsa dan pemberian mulsa, namun dengan menggunakan mulsa plastik jumlah cabang lebih banyak. Penggunaan mulsa plastik hitam maupun mulsa plastik perak dapat memodifikasi keseimbangan dari unsur hara dan air yang dibutuhkan oleh tanaman jadi pertumbuhan dari perakaran akan baik. Pertumbuhan akar yang baik mempengaruhi pertumbuhan tajuk tanaman. Akar akan menyerap air tanah dan unsur hara yang selanjutnya diangkut melalui jaringan xylem menuju organ-organ yang mensintesis dalam suatu proses yang disebut fotosintesis. Hasil fotosintesis (fotosintat) ditranslokasikan ke seluruh jaringan tanaman melalui jaringan floem dan akan bergerak kedua arah yaitu ke arah atas dan bawah menuju daerah pemanfaatannya. Pergerakan substansi ke atas membantu pertumbuhan tajuk (cabang, pucuk dan daun) sehingga jumlah daun menjadi bertambah (Kusumasiwi et al., 2011).

\section{Jumlah Daun}

Berdasarkan sidik ragam diperoleh hasil perlakuan mulsa berbeda nyata sedangkan perlakuan dosis pupuk $\mathrm{KCl}$ dan interaksi antara kalium dan mulsa belum menunjukkan pengaruh yang nyata. Adapun hasil pengamatan terhadap pertumbuhan jumlah cabang dapat dilihat di tabel 3. 
Tabel 3. Jumlah daun ubi jalar umur 7 MST pada pemberian dosis KCl dan jenis mulsa

\begin{tabular}{lccc}
\hline \multicolumn{1}{c}{ Perlakuan } & \multicolumn{3}{c}{ Jenis Mulsa } \\
\hline \multicolumn{1}{c}{ Dosis KCl (g/tan) } & Tanpa mulsa & Mulsa Jerami & \multirow{2}{*}{ Mulsa Plastik } \\
\hline 3.75 gram & 255.00 & 283.33 & 293.67 \\
7.5 gram & 273.67 & 298.00 & 289.33 \\
11.25 gram & 254.67 & 332.33 & 294.33 \\
15 gram & 289.33 & 294.33 & 290.67 \\
\hline Rata-rata & $268.17 \mathrm{c}$ & $302.00 \mathrm{a}$ & $292.00 \mathrm{~b}$ \\
\hline
\end{tabular}

Keterangan : angka yang ditunjukkan oleh huruf yang sama pada baris yang sama menunjukkan tidak berbeda nyata berdasarkan uji Duncan pada taraf $\alpha-5 \%$

Pemberian mulsa jerami membentuk jumlah daun ubi jalar umur 7 minggu yang tertinggi yaitu 302,00 dan perlakuan jenis mulsa terendah terdapat perlakuan tanpa pemberian mulsa. Adrianus (2012) menjelaskan bahwa jumlah daun yang dihasilkan tergantung pada jumlah buku dan jumlah cabang. Buku-buku batang tanaman nantinya akan munculnya tunas-tunas samping yang akan tumbuh menjadi cabang di setiap ketiak daun. Cabang ini juga berbukubuku dan menghasilkan daun.

\section{Laju Tumbuh Tanaman (mg cm${ }^{-2}$ hari $\left.^{-1}\right)$}

. Berdasarkan hasil sidik ragam diperoleh semua perlakuan belum menunjukkan pengaruh yang nyata terhadap laju tumbuh tanaman. Adapun grafik rataan laju tumbuh tanaman dapat dilihat pada Gambar 5.

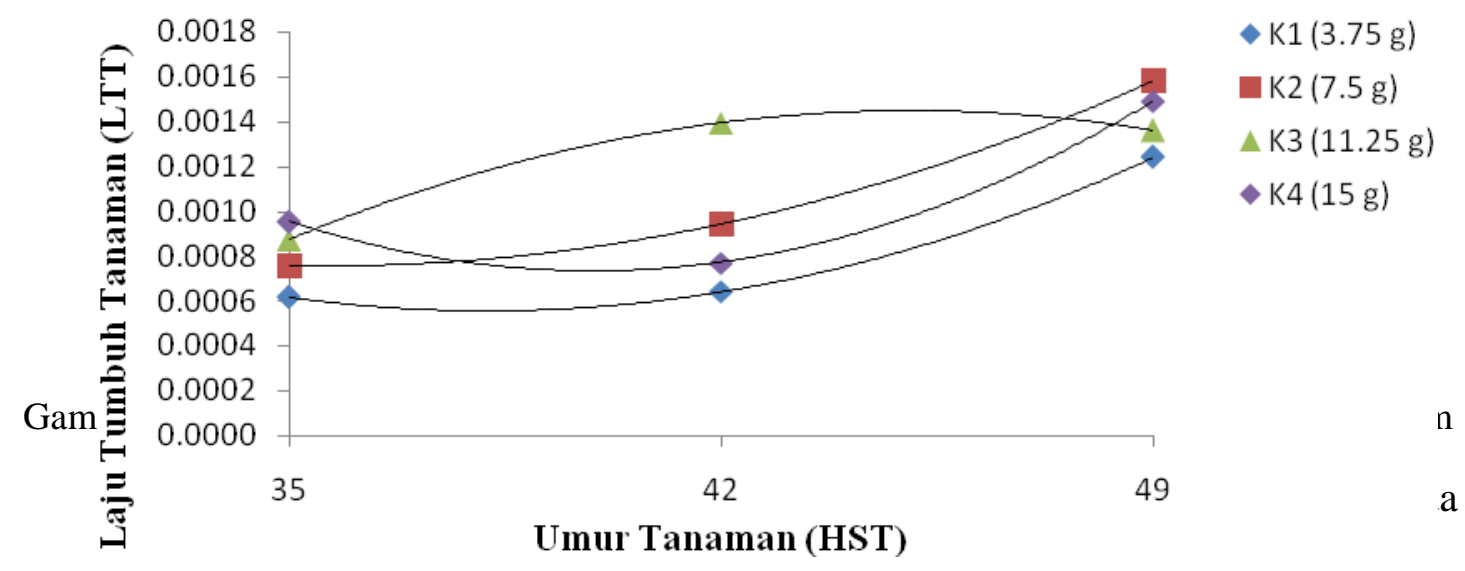

masing-masing perlakuan pupuk kalium dari umur tanaman 35 HST hingga 49 HST pada laju tumbuh tanaman. Berdasarkan Gambar 5 dapat diketahui bahwa penggunaan pupuk kalium menunjukkan peningkatan laju tumbuh tanaman. Laju tumbuh tanaman termasuk laju pertambahan berat kering biomassa total tanaman per satuan luas tanah per satuan waktu rata 
rata selama periode waktu tertentu. Bobot kering yang tinggi cenderung akan meningkatkan laju tumbuh tanaman dan bobot kering tanaman berkaitan erat dengan proses fotosintesis pada daun. Laju tumbuh tanaman yang tidak nyata tersebut dapat diduga karena bagian tajuk tanaman saling menaungi satu sama lain akibat sulur yang memanjang sehingga meningkatkan kerapatan tanaman sehingga menyebabkan laju tumbuh tanaman menjadi tidak nyata terhadap aplikasi pupuk. Gardner et al. (1991) menjelaskan bahwa kerapatan yang tinggi merupakan kondisi lingkungan yang tidak menguntungkan yang dapat menyebabkan penyempitan sehingga tidak akan meningkatkan hasil. Selain itu kerapatan yang tinggi akibat adanya pemanjangan sulur menyebabkan pertumbuhan tanaman menjadi terhambat Susanto et al. (2014) menjelaskan bahwa pada daun yang di tutupi tidak sanggup menyerap cahaya matahari secara maksimal, jadi proses fotosintesis tidak dapat menghasilkan karbohidrat yang cukup untuk pertumbuhan.

\section{Indeks Luas Daun (mg cm${ }^{-2}$ hari $\left.^{-1}\right)$}

Sesuai hasil pengamatan ini dapat diperoleh, bahwa indeks luas daun pada saat 49 HST belum menunjukkan perbedaan yang nyata. Tabel rataan antara $\mathrm{KCl}$ dan mulsa dilihat di Tabel 4.

Tabel 4. Indeks luas daun pada pemberian $\mathrm{KCl}$ dan jenis mulsa saat tanaman umur 49 HST

\begin{tabular}{lccc}
\hline Perlakuan & \multicolumn{3}{c}{ Jenis Mulsa } \\
\cline { 2 - 4 } Dosis KCl (g/tan) & Tanpa Mulsa & Mulsa Jerami & Mulsa plastik \\
\hline 3.75 gram & 4.14 & 3.85 & 3.93 \\
7.5 gram & 3.75 & 5.12 & 3.81 \\
11.25 gram & 2.58 & 3.85 & 4.90 \\
15 gram & 4.29 & 4.62 & 4.05 \\
\hline
\end{tabular}

Berdasarkan Tabel 4. dapat diketahui bahwa perlakuan kalium dan mulsa tidak menunjukkan adanya perbedaan pada indeks luas daun tanaman. Sejalan dengan penelitian Jedeng (2011) yang mendapatkan hasil bahwa parameter indeks luas daun tidak nyata. Hal ini disebabkan oleh berbagai faktor adanya tumpang tindih antar daun tanaman yang menyebabkan beberapa daun tidak mendapatkan cahaya matahari yang optimal sehingga fotosintesis menjadi tidak maksimal. Rahmiana (2015) menjelaskan bahwa ubi jalar termasuk tanaman yang memiliki 
jumlah daun banyak dan susunan daun horizontal. Daun ubi jalar yang bersifat tumpang tindih menyebabkan hasil asimilat tidak maksimal.

Peningkatan indeks luas daun sejalan dengan produksi bahan kering tanaman sampai pada batas optimum. menurut Jumin (2002) meningkatnya hasil bahan kering sejalan dengan meningkatnya indeks luas daun sampai batas optimum. Dengan demikian, hal yang mungkin diduga berpengaruh terhadap indeks luas daun adalah produksi bahan kering tanaman yang tidak berbeda nyata karena perbedaan indeks luas daun menjadi tidak nyata. Susanto et al. (2014) menjelaskan bahwa luas daun yang sempit menyebabkan radiasi matahari yang ditangkap tanaman tidak optimal, sehingga dapat berpengaruh terhadap proses fotosintesis.

\section{Laju Asimilasi Bersih (mg cm${ }^{-2}$ hari $\left.^{-1}\right)$}

Hasil pengamatan ini dapat dilihat di Lampiran 28, 30 dan 32. Berdasarkan hasil sidik ragam diperoleh hasil bahwa Laju Asimilasi bersih, perlakuan dosis pupuk kalium dan mulsa tidak menunjukkan pengaruh yang nyata. Adapun hasil rataan perlakuan dapat dilihat pada Gambar 6.

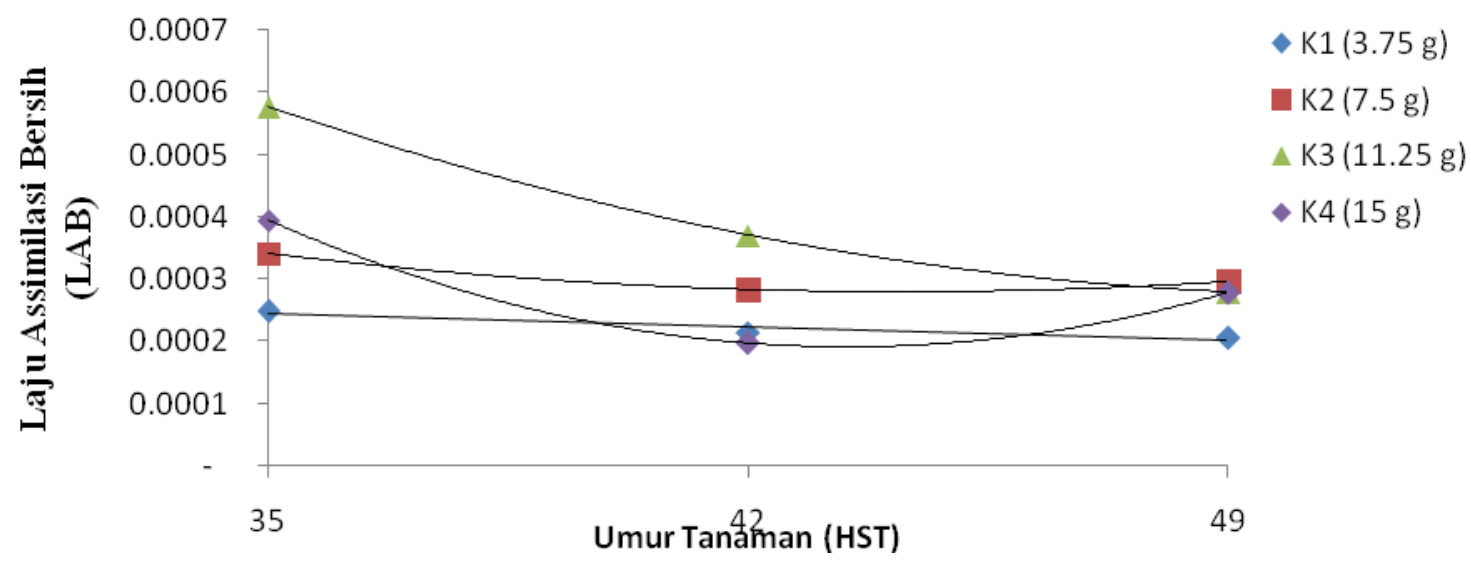

Gambar 6. Laju Assimilasi Bersih (LAB) saat 35 HST, 42 HST dan 49 HST pada perlakuan kalium

Berdasarkan Gambar 6. dapat diketahui bagaimana grafik yang terbentuk pada masingmasing pemberian pupuk kalium dari umur tanaman 35 HST hingga 49 HST pada laju assimilasi bersih menunjukkan penurunan. 
Kalium merupakan komponen unsur hara yang dibutuhkan tanaman untuk menjalankan proses fisiologis, salah satu fungsi dari kalium adalah dapat meningkatkan transportasi zat di dalam tubuh tanaman. Damanik et al. (2010) menjelaskan bahwa kalium adalah unsur hara makro yang bersifat mobile sehingga berpengaruh pada proses transportasi hara dari tanah keseluruh bagian tanaman atau dari bagian daun keseluruh bagian tanaman. Salisbury dan Ross (1991) menjelaskan bahwa pada daun unsur kalium dapat berpengaruh pada tekanan turgor daun yang berfungsi pada mekanisme membuka dan menutupnya stomata.

Namun, pada penelitian ini respon tanaman yang diberi kalium terhadap laju assimilasi bersih tidak nyata. Hal tersebut dapat terjadi karena berbagai faktor, Jumin (2002) menjelaskan bahwa ada faktor lingkungan yang dapat mempengaruhi efektivitas pemupukan. Berdasarkan morfologi tanaman, ubi jalar tumbuh secara merambat sehingga akan meningkatkan angka kerapatan tanaman terutama pada bagian tajuk. Hal tersebut mendorong terjadinya kompetisi pada daerah tajuk untuk memperebutkan sinar matahari sehingga bagian daun terkena sinar matahari menjadi berkurang sehingga akan berpengaruh terhadap proses fotosintesis yang akhirnya sangat berpengaruh terhadap laju assimilasi bersih.

\section{Kesimpulan}

\section{KESIMPULAN}

Berdasarkan hasil penelitian dapat ditarik kesimpulan sebagai berikut :

1. Perlakuan interaksi antara kalium dan mulsa menunjukkan pengaruh yang nyata pada parameter jumlah cabang, Indeks Luas Daun (ILD) 35 HST, ILD 42 HST dan Laju Assimilasi Bersih (LAB) 35 HST.

2. Perlakuan kalium berpengaruh nyata pada parameter jumlah cabang, jumlah daun 4 MST dan 6 MST, Laju Tumbuh Umbi (LTU) 35 HST, diameter umbi, berat umbi pertanaman dan produksi umbi per hektar. 


\section{DAFTAR PUSTAKA}

Damanik, M. M. B., B. E. Hasibuan., Fauzi., Sarifuddin., dan H. Hanum. 2010. Kesuburan Tanah dan Pemupukan. USU Press, Medan.

Dessy Eresina Pinem, Bambang Benediktus Sianipar dan Purnama. 2015.Kajian Alokasi Kebutuhan Ruang di Provinsi Sumatera Utara. Jurnal Wilayah Dan Lingkungan. Vol.3.

Gardner, F. P. ; R. B. Pearce dan R. L. Mitchell. 1991. Fisiologi Tanaman Budidaya. Terjemahan: Herawati Susilo. UI Press, Jakarta.

Jedeng, I.W. 2011. Pengaruh jenis dan dosis pupuk organik terhadap pertumbuhan dan hasil ubi jalar (Ipomea batatas (L.) Lamb.) Var. Lokal Ungu. Tesis. Program Pasca Sarjana. Universitas Udayana. Denpasar. Bali.

Jumin, 2010.Dasar-Dasar Agroklimatologi. Agro Persada. Jakarta.

Juanda, D. dan Bambang Cahyono.2000.Ubi Jalar Budi Daya dan Analisis Usaha Tani. Penerbit Kanisius. Yogyakarta

Kusumasiwi A.W.P., Sri Muhartini, Sri Trisnowati. 2011. Pengaruh Warna Mulsa Plastik Terhadap Pertumbuhan dan hasil Terung (Solanum melongena L.) Tumpang Sari Dengan Kangkung Darat (Ipomoea reptans Poir.). Fakultas pertanian Gadjah Mada, Yogyakarta. p: 4-7

Mariano, A.S.A. 2003. Pengaruh Pupuk Foska dan Mulsa Jerami terhadap Beberapa Sifat Fisik dan Kimia Tanah serta Produksi Kedelai(Glycine L. Merr.). Program Studi Ilmu Tanah Departemen Tanah, Fakultas Pertanian, Institut Pertanian Bogor. Hal. 11-12.

Nelson, W.A., B.A. Kahn and B.W. Roberts. 1991. Screening cover crops for use in conservation tillage system for vegetables following spring plowing. Hort.Sci. 26:860-862

Poerwowidodo.1992.Telaah Kesuburan Tanah.Bandung:Angkasa.

Purwono, L dan Purnamawati. 2007. Budidaya Tanaman Pangan. Penerbit Agromedia. Jakarta.

Richana, 2012, Ubi Kayu dan Ubi Jalar.Nuansa. Bogor

Rahmiana E.A., Tyasmoro S.T. dan Suminarti N.E. 2015. Pengaruh pengurangan panjang sulur dan frekuensi pembalikan batang pada pertumbuhan dan hasil tanaman ubi jalar (Ipomoea batatas L.). Jurnal Produksi Tanaman. 3(2):126- 134.

Salisburry, T dan Ross, R. 1991. Fisiologi Tumbuhan Jilid 1. ITB Press. Bandung.

Sonhaji A, 2007, Mengenal Ubi Jalar, Gaza Publishing, Tasik Malaya.

Sumiati, E. 2005. Pertumbuhan dan Hasil Kentang dengan Aplikasi NPK 15-15-15 dan Pupuk 
Susanto, E., Herlina, N. dan Suminarti, N.E., 2014. Respon pertumbuhan dan hasil tanaman ubi jalar (Ipomea batatas L.) pada beberapa macam dan waktu aplikasi organik. Jurnal produksi tanaman. 2(5) : 412-418.

Syukur, M., Sujiprihati, Yunianti, R. 2015. Teknik Pemuliaan Tanaman. Penebar Swadaya. Jakarta.

Thomas, R.S., R.L. Franson, \& G.J. Bethlenfalvay. 1993. Separation of VAM Fungus and Root Effect,s on Soil Agregation. Soil Sci. Am. J. Edition : 57 : 77-31.

Tisdale, S. L., W. L. Nelson, J. D. Beaton. 1990. Soil Fertility and Fertilizer Macmillan Pub. Co. New York. 00 p. 